\title{
Hyperuricemia as an Additional Risk Factor for Coronary Artery Disease: A Hospital Based Case Control Study in Western Region of Nepal
}

\author{
Mittal A ${ }^{1}$, Sathian B ${ }^{2}$, Kumar A3 , Chandrasekharan N ${ }^{4}$, Farooqui MS ${ }^{5}$, Singh S6, Yadav KS
}

${ }^{1}$ Associate Professor, Department of Biochemistry, Manipal College of Medical Sciences, Pokhara,Nepal.

${ }^{2}$ Assistant Professor, Department of Community Medicine, Manipal College of Medical Sciences, Pokhara, Nepal.

${ }^{3}$ Associate Professor, Department of Biochemistry, International Medical University, Kuala Lumpur, Malaysia.

${ }^{4}$ Assistant Professor, Department of Orthopaedics, Manipal College of Medical Sciences, Pokhara, Nepal.

${ }^{5}$ MBBS Intern, Manipal College of Medical Sciences, Pokhara, Nepal.

${ }^{6}$ MBBS Student, Manipal College of Medical Sciences, Pokhara, Nepal.

${ }^{7}$ Laboratory Technologist, Department of Biochemistry, Manipal College of Medical Sciences, Pokhara, Nepal.

\section{Original Article}

\section{Corresponding Author:}

Dr. Ankush Mittal, Associate Professor, Department of Biochemistry, Manipal College of Medical Sciences, Pokhara, Nepal

Email:drmittala@gmail.com

\section{Abstract}

\section{Background}

In the 21st century, cardiovascular diseases will continue to dominate the disease spectrum and death statistics in both the industrialized and developing worlds. Coronary artery disease (CAD) is the foremost cause of cardiovascular disease related deaths worldwide, with $>4.5$ million deaths taking place in the developing world. Augmented serum uric acid levels are recurrently come across with hyperlipidemia, atherosclerosis, obesity, glucose intolerance, renal disease, and hypertension which all play a fundamental role in the pathogenesis of coronary artery disease.

\section{Materials and methods}

It was a hospital based case control study carried out in the Department of Biochemistry of Manipal Teaching Hospital, Pokhara, Nepal between $1^{\text {st }}$ January 2010 and $31^{\text {st }}$ December 2010. The variables collected were age, gender, serum uric acid, total cholesterol, low density lipoproteins, triglycerides, high density lipoproteins and very low density lipoproteins. Approval for the study was obtained from the institutional research ethical committee.

\section{Results}

There was insignificant difference for age between groups. In cases of hyperuricemia, there was marked increase in levels of serum uric acid $(8.043 \pm 0.43 \mathrm{mg} / \mathrm{dl})$ when compared to controls $(4.28 \pm 0.66 \mathrm{mg} / \mathrm{dl}$. In patients suffering from coronary artery disease with hyperuricemia, there was marked increased in levels of serum uric $\operatorname{acid}(8.222 \pm 0.39 \mathrm{mg} / \mathrm{dl})$ found to be statistically significant when compared to controls ( $4.285 \pm 0.66 \mathrm{mg} / \mathrm{dl}$ ) and values were quite similar to hyperuricemic patients $(8.043 \pm 0.43$ $\mathrm{mg} / \mathrm{dl})$.Further, in patients suffering from coronary artery disease with hyperuricemia, there was marked increased in mean values of serum total cholesterol $(257.56 \pm 22.65$ $\mathrm{mg} / \mathrm{dl})$ ) when compared to controls $(173.22 \pm 32.63 \mathrm{mg} / \mathrm{dl})$.

\section{Conclusion}

Hypercholesterolemia due to hyperuricemia is most common modifiable factor for coronary artery disease. Allopurinol and newer urate-lowering agents restores endothelial function in coronary artery disease patients. The ability of physicians to pharmacologically manage serum urate levels, a better understanding of the interaction between hyperuricemia, gout and vascular disease may be critical for the reduction of morbidity and mortality in highrisk coronary artery disease patients.

Key words: Hyperuricemia, Coronary artery disease, Nepal 


\section{Background}

In the 21st century, cardiovascular diseases will continue to dominate the disease spectrum and death statistics in both the industrialized and developing worlds ${ }^{1}$. By 2020, it is anticipated that CVD will turn out to be the leading cause of the global health burden, accounting for 73 percent of total global mortality and 56 percent of total morbidity. Developing countries are now enduring an epidemiological adaptation due to progressive urbanization and westernization of their life style. This can lead to new epidemiological situation in the world with a decline in infectious diseases and emergence of noncommunicable diseases ${ }^{2}$. Among the cardiovascular diseases, coronary artery disease (CAD), which is caused by atherosclerosis, is the major widespread cause of death worldwide and is accountable for financial loss, efficiency, disability and death more than any other noncommunicable disease ${ }^{3}$.

Coronary artery disease (CAD) is the foremost cause of cardiovascular disease related deaths worldwide, with $>4.5$ million deaths taking place in the developing world. In the face of a recent decline in urbanized countries, an increase in both CAD mortality and frequency of CAD risk factors have been seen in developing countries ${ }^{4}$. Mortality due to coronary artery disease is roughly 16 million yearly worldwide and it is projected to heave two times in the next 20 years with $80 \%$ amplification in developing countries ${ }^{5}$. In recent years, compelling epidemiological and clinical information have constantly favoured an etiological association between hyperuricemia and coronary artery disease ${ }^{6}$.

Hyperuricemia and gout are closely related conditions that also have an indirect influence on progress of CAD by physical activity restraint, primarily caused by persistent acute gout flares which sequentially cause sedentary form of life leading to obesity. Obesity is a known risk factor diabetes, lipid disorders and hypertension ${ }^{7}$. Women are more prone to hyperuricemia and its associated severity of coronary artery disease than men. Augmented serum uric acid levels are recurrently come across with hyperlipidemia, atherosclerosis, obesity, glucose intolerance, renal disease, and hypertension which all play a fundamental role in the pathogenesis of coronary artery disease ${ }^{8}$.

Major modifiable risk factor that initiate or stimulate the process of atherosclerosis include diabetes mellitus, hypertension, stress, smoking, alcohol, increase plasma lipoproteins, oxidized low density lipoprotein, oral contraceptives, lack of exercise, obesity and poor $\operatorname{diet}^{9}$. Hyperuricemia leads to 3 to 5 fold increased risk of experience coronary artery disease or cerebrovascular disease. Although the mechanism by which uric acid may play a pathogenetic role in cardiovascular disease is unclear, hyperuricemia is allied with deleterious effects on endothelial dysfunction, oxidative metabolism, platelet adhesiveness and aggregation ${ }^{10}$.

The aim of the present study was to look into the various coronary artery disease risk factors allied with hyperuricemia in Pokhara valley, Nepal.

\section{Materials and methods}

It was a hospital based case control study carried out in the Department of Biochemistry of Manipal Teaching Hospital, Pokhara, Nepal between $1^{\text {st }}$ January 2010 and $31^{\text {st }}$ December 2010. The variables collected were age, gender, serum uric acid, total cholesterol, low density lipoproteins, triglycerides, high density lipoproteins and very low density lipoproteins. Approval for the study was obtained from the institutional research ethical committee.

Estimation of uric acid was done by enzymatic method ${ }^{11}$. Estimation of total cholesterol and triglycerides was done by CHOD-PAP and GPO-PAP method respectively ${ }^{12}$. Estimation of high density lipoproteins was done by kinetic enzymatic method $^{13}$. The values of low-density lipoprotein cholesterol (LDL) and triglycerides were obtained by the Friedewald formula ${ }^{14}$.

All these laboratory parameters were analyzed using Human reagent kits and with the help of semi autoanalyser (Human, Germany). Analysis was done using descriptive statistics and testing of hypothesis. The data was analyzed using Excel 2003, R 2.8.0 Statistical Package for the Social Sciences (SPSS) for Windows Version 16.0 (SPSS Inc; Chicago, IL, USA) and the EPI Info 3.5.1 Windows Version. The One way ANOVA was used to examine the statistical significant difference between groups. Post Hoc test LSD used for the comparison of means of control versus case groups. A p-value of $<0.05$ (two-tailed) was used to establish statistical significance.

Inclusion criteria:- Patients having definite diagnosis of gout based on monosodium urate monohydrate crystals identified by polarized, compensated, microscopic examination of samples of synovial fluid or tophus aspirate and average serum uric acid levels $\geq 7.0 \mathrm{mg} / \mathrm{dl}$ were included. Patients having coronary artery disease at baseline with positive medical history, clinician assessment and electrocardiogram were also evaluated. Healthy controls were volunteers employed at Manipal Teaching Hospital, Pokhara with no positive history of hyperuricemia and coronary artery disease.

Exclusion criteria:- Patients with previous history of smoking, alcohol intake, hypertension, cancer or renal, valvular heart disease, systolic blood pressure, on diuretics were excluded.

\section{Results}

Of 1200 subjects, 900 were cases and rest 300 were controls. Cases taken were of hyperuricemia , coronary artery disease, coronary artery disease with hyperuricemia. For all subjects, mean values and confidence interval was calculated with all variables taken into our study. 
Table 1: Details of mean values of variables in controls and cases

\begin{tabular}{|c|c|c|c|c|c|}
\hline Variables & $\begin{array}{l}\text { Controls } \\
(300) \\
\text { Mean } \pm S D(C I)\end{array}$ & $\begin{array}{l}\text { Hyperuricemia } \\
(300) \\
\text { Mean } \pm S D(C l)\end{array}$ & \begin{tabular}{|l|} 
CAD \\
$(300)$ \\
Mean $\pm S D(C l)$
\end{tabular} & $\begin{array}{l}\text { CAD } \\
\text { withhyper } \\
\text { uricemia } \\
(300) \\
\text { Mean } \pm \text { SD } \\
(\mathrm{Cl})\end{array}$ & $p$ value \\
\hline Age & $\begin{array}{l}56.5 \pm 5.6 \\
(55.8,57.1)\end{array}$ & $\begin{array}{l}56.2 \pm 6.1 \\
(55.5,56.9)\end{array}$ & $\begin{array}{l}56.8 \pm 6.4 \\
(56.1,57.5)\end{array}$ & $\begin{array}{l}56.3 \pm 5.4 \\
(55.7,56.9)\end{array}$ & 0.668 \\
\hline $\begin{array}{l}\text { Serum } \\
\text { uric acid }\end{array}$ & $\begin{array}{l}4.2 \pm 0.6 \\
(4.2,4.3)\end{array}$ & $\begin{array}{l}8.1 \pm 0.4 \dagger \\
(7.9,8.1)\end{array}$ & $\begin{array}{l}4.29 \pm 0.64 \\
(4.2,4.3)\end{array}$ & $\begin{array}{l}8.2 \pm 0.3^{\dagger} \\
(8.17,8.26)\end{array}$ & $0.0001^{* *}$ \\
\hline TC & $\begin{array}{l}173.2 \pm 32.6 \\
(169.5,176.9)\end{array}$ & $\begin{array}{l}222.5 \pm 22.6+ \\
(220.1,225.1)\end{array}$ & $\begin{array}{l}227.7 \pm 22.6+ \\
(225.2,230.3)\end{array}$ & $\begin{array}{l}257.5 \pm 22.6 \dagger \\
(254.9,260.1)\end{array}$ & $0.0001^{* *}$ \\
\hline TG & $\begin{array}{l}115.0 \pm 25.12 \\
(112.2,117.9)\end{array}$ & $\begin{array}{l}121.6 \pm 37.1 \dagger \\
(117.4,125.9)\end{array}$ & $\begin{array}{l}129.5 \pm 39.8^{+} \\
(125.0,134.0)\end{array}$ & $\begin{array}{l}139.4 \pm 39.8^{\dagger} \\
(134.9,144.0)\end{array}$ & $0.0001^{* *}$ \\
\hline HDL & $\begin{array}{l}42.8 \pm 1.9 \\
(42.6,43.1)\end{array}$ & $\begin{array}{l}42.5 \pm 2.3^{\dagger} \\
(42.2,42.8)\end{array}$ & $\begin{array}{l}41.5 \pm 2.2+ \\
(41.3,41.8)\end{array}$ & $\begin{array}{l}42.9 \pm 1.5 \\
(42.8,43.1)\end{array}$ & $0.0001 * *$ \\
\hline LDL & $\begin{array}{l}104.4 \pm 25.4 \\
(101.5,107.2)\end{array}$ & $\begin{array}{l}157.4 \pm 49.7+ \\
(151.7,163.1)\end{array}$ & $\begin{array}{l}160.1 \pm 23.9 \dagger \\
(157.4,162.8)\end{array}$ & $\begin{array}{l}186.6 \pm 24.0 \dagger \\
(183.9,189.4)\end{array}$ & $0.0001^{* *}$ \\
\hline VLDL & $\begin{array}{l}23.0 \pm 4.85 \\
(22.4,23.5)\end{array}$ & $\begin{array}{l}25.1 \pm 7.8^{\dagger} \\
(24.1,25.9)\end{array}$ & $\begin{array}{l}25.9 \pm 7.8^{+} \\
(25.1,26.8)\end{array}$ & $\begin{array}{l}27.9 \pm 7.9+ \\
(27.1,28.8)\end{array}$ & $0.0001^{* *}$ \\
\hline
\end{tabular}

** $p$ value $<0.001$ statistical significance between groups

$+p$ value $<0.05$ the mean difference is statistically significant in the comparison of control versus case groups

Table 1 depicts the alteration in mean values for age in years of variables in controls and cases. There was insignificant difference for age between groups. In cases of hyperuricemia, there was marked increase in levels of serum uric acid $(8.043 \pm 0.43 \mathrm{mg} / \mathrm{dl})$ when compared to controls $(4.28 \pm 0.66 \mathrm{mg} / \mathrm{dl})$. In patients of coronary artery disease, mean values of serum uric acid levels (4.299 \pm $0.64 \mathrm{mg} / \mathrm{dl}$ ) were found to be statistically insignificant when compared with controls $(4.285 \pm 0.66 \mathrm{mg} / \mathrm{dl})$. In patients suffering from coronary artery disease with hyperuricemia, there was marked increased in levels of serum uric acid $(8.222 \pm 0.39 \mathrm{mg} / \mathrm{dl})$ found to be statistically significant when compared to controls $(4.285 \pm 0.66 \mathrm{mg} / \mathrm{dl})$ and values were quite similar to hyperuricemic patients $(8.043 \pm 0.43$ $\mathrm{mg} / \mathrm{dl}$ ). Further, in hyperuricemia patients, there was moderate increase in mean values of serum total cholesterol $(222.59 \pm 22.65 \mathrm{mg} / \mathrm{dl})$ when compared to controls $(173.22 \pm 32.63 \mathrm{mg} / \mathrm{dl})$.

In cases of coronary artery disease, mean values of serum total cholesterol $(227.78 \pm 22.652 \mathrm{mg} / \mathrm{dl})$ were found to be raised and values were quite similar to hyperuricemic patients $(222.59 \pm 22.65 \mathrm{mg} / \mathrm{dl})$. In patients suffering from coronary artery disease with hyperuricemia, there was marked increased in mean values of serum total cholesterol $(257.56 \pm 22.65 \mathrm{mg} / \mathrm{dl}))$ when compared to controls (173.22 $\pm 32.63 \mathrm{mg} / \mathrm{dl})$.

All the case groups were found to be statistically significant with serum total cholesterol when compared to controls. In addition to that, there was mild increase in mean values of serum triglycerides in patients of hyperuricemia $(121.69 \pm 37.12 \mathrm{mg} / \mathrm{dl})$ and coronary artery disease (129.53 \pm $39.82 \mathrm{mg} / \mathrm{dl}$ ) when compared to controls (115.08 \pm $25.122 \mathrm{mg} / \mathrm{dl}$. In patients suffering from coronary artery disease with hyperuricemia, there was moderate increase in mean values of serum triglycerides $(139.48 \pm 39.807 \mathrm{mg} / \mathrm{dl})$ when compared to controls $(115.08 \pm 25.122 \mathrm{mg} / \mathrm{dl})$. All the case groups were found to be statistically significant with serum triglycerides when compared to controls. The mean values of HDL for all cases were found to be statistically significant when compared to controls.

Table 2: Details of mean values of variables for controls and cases in males

\begin{tabular}{|c|c|c|c|c|c|}
\hline Variables & $\begin{array}{l}\text { Controls } \\
(125) \\
\text { Mean } \pm S D(C l)\end{array}$ & $\begin{array}{l}\text { Hyperuricemia } \\
(96) \\
\text { Mean } \pm S D(C I)\end{array}$ & $\begin{array}{l}\text { CAD } \\
(127) \\
\text { Mean } \pm S D(C I)\end{array}$ & $\begin{array}{l}\text { CAD with hyper } \\
\text { uricemia } \\
(119) \\
\text { Mean } \pm \text { SD (CI) }\end{array}$ & p value \\
\hline Age & $\begin{array}{l}55.7 \pm 4.9 \\
(54.9,56.6)\end{array}$ & $\begin{array}{l}56.88 \pm 7.9 \\
(55.27,58.4)\end{array}$ & $\begin{array}{l}56.36 \pm 5.7 \\
(55.3,57.3)\end{array}$ & $\begin{array}{l}54.8 \pm 2.8 \\
(54.3,55.4)\end{array}$ & 0.050 \\
\hline $\begin{array}{l}\text { Serum uric } \\
\text { acid }\end{array}$ & $\begin{array}{l}4.35 \pm 0.63 \\
(4.24,4.46)\end{array}$ & $\begin{array}{l}8.08 \pm 0.4^{\dagger} \\
(7.99,8.1)\end{array}$ & $\begin{array}{l}4.27 \pm 0.65 \\
(4.16,4.39)\end{array}$ & $\begin{array}{l}8.3 \pm 0.3^{\dagger} \\
(8.2,8.4)\end{array}$ & $0.0001 * *$ \\
\hline TC & $\begin{array}{l}173.4 \pm 32.8 \\
(167.6,179.2)\end{array}$ & $\begin{array}{l}220.2 \pm 20.5^{\dagger} \\
(216.0,224.3)\end{array}$ & $\begin{array}{l}230.4 \pm 21.1 \dagger \\
(226.7,234.1)\end{array}$ & $\begin{array}{l}260.3 \pm 21.2 \dagger \\
(256.5,264.2)\end{array}$ & $0.0001 * *$ \\
\hline TG & $\begin{array}{l}112.7 \pm 25.8 \\
(108.1,117.2)\end{array}$ & $\begin{array}{l}114.9 \pm 38.2 \\
(107.1,122.6)\end{array}$ & $\begin{array}{l}127.9 \pm 38.2 \dagger \\
(121.2,134.6)\end{array}$ & $\begin{array}{l}141.5 \pm 34.9 \dagger \\
(135.1,147.8)\end{array}$ & $0.0001 * *$ \\
\hline $\mathrm{HDL}$ & $\begin{array}{l}42.7 \pm 2.1 \\
(42.3,43.1)\end{array}$ & $\begin{array}{l}42.7 \pm 2.2 \\
(42.3,43.2)\end{array}$ & $\begin{array}{l}41.6 \pm 2.3^{\dagger} \\
(41.7,42.0)\end{array}$ & $\begin{array}{l}43.6 \pm 1.4{ }^{\dagger} \\
(43.3,43.8)\end{array}$ & $0.0001 * *$ \\
\hline LDL & $\begin{array}{l}105.5 \pm 26.5 \\
(100.8,110.2)\end{array}$ & $\begin{array}{l}153.7 \pm 22.4^{\dagger} \\
(149.2,158.3)\end{array}$ & $\begin{array}{l}163.0 \pm 22.5^{\dagger} \\
(159.0,167.0)\end{array}$ & $\begin{array}{l}188.5 \pm 26.0^{\dagger} \\
(183.8,193.2)\end{array}$ & $0.0001 * *$ \\
\hline VLDL & $\begin{array}{l}22.53 \pm 4.98 \\
(21.6,23.41)\end{array}$ & $\begin{array}{l}23.70 \pm 8.1 \\
(22.04,25.3)\end{array}$ & $\begin{array}{l}25.62 \pm 7.48+ \\
(24.3,26.9)\end{array}$ & $\begin{array}{l}28.24 \pm 6.9^{\dagger} \\
(26.98,29.5)\end{array}$ & $0.0001 * *$ \\
\hline
\end{tabular}

** $p$ Value $<0.001$ statistical significance between groups $+p$ value $<0.05$ the mean difference is statistically significant in the comparison of control versus case groups

Table 2 displays that the number of males suffering from hyperuricemia (96) and coronary artery disease (127) was far less in comparison to females. The mean values of serum uric acid in patients of hyperuricemia $(8.08 \pm 0.46 \mathrm{mg} / \mathrm{dl})$ and coronary artery disease with hyperuricemia (8.35 \pm $0.36 \mathrm{mg} / \mathrm{dl}$ ) were found to be stastically significant when compared to controls $(4.35 \pm 0.63 \mathrm{mg} / \mathrm{dl})$ in males. All the case groups were found to be statistically significant with serum total cholesterol when compared to controls in males. In addition to that the mean values of serum triglycerides in patients of coronary artery disease (127.93 \pm 38.24) and coronary artery disease with hyperuricemia $(129.53 \pm 39.82 \mathrm{mg} / \mathrm{dl})$ when compared to controls (115.08 $\pm 25.122 \mathrm{mg} / \mathrm{dl})$. Further, the mean values of HDL in cases of coronary artery disease $(41.68 \pm 2.31 \mathrm{mg} / \mathrm{dl})$ and CAD with hyperuricemia $(43.61 \pm 1.403 \mathrm{mg} / \mathrm{dl})$ were found to be stastically significant when compared to controls (42.74 $\pm 2.068 \mathrm{mg} / \mathrm{dl})$. 
Table 3: Details of mean values of variables for controls and cases in females

\begin{tabular}{|c|c|c|c|c|c|}
\hline Variables & \begin{tabular}{|l} 
Controls \\
$(175)$ \\
Mean $\pm S D(C I)$
\end{tabular} & $\begin{array}{l}\text { Hyperuricemia } \\
(204) \\
\text { Mean } \pm \text { SD (CI) }\end{array}$ & $\begin{array}{l}\text { CAD } \\
(173) \\
\text { Mean } \pm S D(C I)\end{array}$ & $\begin{array}{l}\text { CAD } \\
\text { withhyper } \\
\text { uricemia } \\
(181) \\
\text { Mean } \pm \text { SD (CI) }\end{array}$ & $p$ value \\
\hline Age & $\begin{array}{l}57.0 \pm 6.10 \\
(56.1,57.9)\end{array}$ & $\begin{array}{l}56.0 \pm 5.16 \\
(55.2,56.7)\end{array}$ & $\begin{array}{l}57.2 \pm 6.9 \\
(56.1,58.2)\end{array}$ & $\begin{array}{l}57.3 \pm 6.3 \\
(56.4,58.3)\end{array}$ & 0.119 \\
\hline $\begin{array}{l}\text { Serum } \\
\text { uric acid }\end{array}$ & $\begin{array}{l}4.23 \pm 0.67 \\
(4.13,4.33)\end{array}$ & $\begin{array}{l}8.2 \pm 0.41 \dagger \\
(97.9,8.08)\end{array}$ & $\begin{array}{l}4.3 \pm 0.64 \\
(4.2,4.4)\end{array}$ & $\begin{array}{l}8.1 \pm 0.3^{\dagger} \\
(8.0,8.1)\end{array}$ & $0.0001^{* *}$ \\
\hline TC & $\begin{array}{l}173.0 \pm 32.5 \\
(168.1,177.9)\end{array}$ & $\begin{array}{l}223.7 \pm 23.5^{\dagger} \\
(220.4,226.9)\end{array}$ & $\begin{array}{l}225.8 \pm 23.6 \dagger \\
(222.2,229.3)\end{array}$ & $\begin{array}{l}255.7 \pm 23.4^{\dagger} \\
(252.2,259.1)\end{array}$ & $0.0001 * *$ \\
\hline TG & $\begin{array}{l}116.7 \pm 24.5 \\
(113.1,120.4)\end{array}$ & $\begin{array}{l}124.8 \pm 36.2 \dagger \\
(119.8,129.8)\end{array}$ & $\begin{array}{l}130.7 \pm 41.1^{\dagger} \\
(124.5,136.8)\end{array}$ & $\begin{array}{l}138.1 \pm 42.7^{\dagger} \\
(131.8,144.4)\end{array}$ & $0.0001 * *$ \\
\hline HDL & $\begin{array}{l}43.0 \pm 1.86 \\
(42.7,43.2)\end{array}$ & $\begin{array}{l}42.4 \pm 2.3^{\dagger} \\
(42.1,42.7)\end{array}$ & $\begin{array}{l}41.5 \pm 2.2+ \\
(41.1,41.8)\end{array}$ & $\begin{array}{l}42.5 \pm 1.4^{\dagger} \\
(42.3,42.7)\end{array}$ & $0.0001^{* *}$ \\
\hline LDL & $\begin{array}{l}103.6 \pm 24.6 \\
(99.9,107.2)\end{array}$ & $\begin{array}{l}159.1 \pm 58.3^{\dagger} \\
(151.1,167.2)\end{array}$ & $\begin{array}{l}158.0 \pm 24.7^{\dagger} \\
(154.3,161.7)\end{array}$ & $\begin{array}{l}185.4 \pm 22.5^{\dagger} \\
(182.1,188.7)\end{array}$ & $0.0001^{* *}$ \\
\hline VLDL & $\begin{array}{l}23.3 \pm 4.74 \\
(22.6,24.0)\end{array}$ & $\begin{array}{l}25.6 \pm 7.6^{\dagger} \\
(24.5,26.6)\end{array}$ & $\begin{array}{l}26.2 \pm 8.1 \dagger \\
(25.0,27.4)\end{array}$ & $\begin{array}{l}27.7 \pm 8.5^{\dagger} \\
(26.4,28.9)\end{array}$ & $0.0001 * *$ \\
\hline
\end{tabular}

** $\mathrm{p}$ Value $<0.001$ statistical significance between groups $+p$ Value $<0.05$ the mean difference is statistically significant in the comparison of control versus case groups

Table 3 illustrates that the number of females suffering from hyperuricemia (204) and coronary artery disease (173) surpassed in comparison to males. The mean values of serum uric acid in patients of hyperuricemia (8.023 \pm $0.41 \mathrm{mg} / \mathrm{dl}$ ) and coronary artery disease with hyperuricemia $(8.134 \pm 0.38 \mathrm{mg} / \mathrm{dl})$ were found to be stastically significant when compared to controls $(4.23 \pm 0.67 \mathrm{mg} / \mathrm{dl})$ in females. All the case groups were found to be statistically significant with serum total cholesterol and triglycerides when compared to controls in females. Further,the mean values of HDL for all cases were found to be stastically significant when compared to controls in females.

Table 4: Logistic Regression analysis for Adjusted odds ratio

\begin{tabular}{|c|c|c|c|c|c|c|c|}
\hline \multirow[t]{2}{*}{$C A D^{a}$} & \multirow[t]{2}{*}{ B } & \multirow[t]{2}{*}{\begin{tabular}{|l} 
Std. \\
Error
\end{tabular}} & \multirow[t]{2}{*}{ Wald } & \multirow[t]{2}{*}{ Sig. } & \multirow[t]{2}{*}{$\operatorname{Exp}(B)$} & \multicolumn{2}{|c|}{$\begin{array}{l}95 \% \text { Confidence Interval } \\
\text { for } \operatorname{Exp}(\mathrm{B})\end{array}$} \\
\hline & & & & & & $\begin{array}{l}\text { Lower } \\
\text { Bound }\end{array}$ & $\begin{array}{l}\text { Upper } \\
\text { Bound }\end{array}$ \\
\hline Intercept & 13.19 & 2.081 & 40.24 & 0.000 & & & \\
\hline TC & -0.025 & 0.011 & 5.086 & .024 & 0.975 & 0.955 & 0.997 \\
\hline TG & -0.021 & 0.016 & 1.65 & 0.198 & 0.979 & 0.949 & 1.01 \\
\hline LDL & -0.043 & 0.012 & 13.81 & 0.000 & 0.958 & 0.936 & 0.980 \\
\hline VLDL & -0.001 & 0.082 & 0.000 & 0.989 & 0.999 & 0.850 & 1.17 \\
\hline HDL & -0.056 & .044 & 1.61 & 0.204 & 0.945 & 0.867 & 1.03 \\
\hline $\begin{array}{l}\text { Serum uric } \\
\text { acid }\end{array}$ & 0.62 & 0.056 & 126.1 & 0.000 & 1.87 & 1.67 & 2.08 \\
\hline
\end{tabular}

a. the reference category.
Table 4 illustrates that there is a 1.87 times risk of developing coronary artery disease for hyperuricemic patients when compared to other groups $(p=0.0001$, Adjusted odds ratio $=1.87$ ).

\section{Discussion}

Hyperuricemia impairs endothelial function and there by gives rise to atherosclerotic risk. A reduction in urate levels is frequently associated with improvement or even resolution of endothelial dysfunction. As more data is gathered, the complexity of hyperuricemia and its relationship to inflammation, atherosclerosis, oxidative stress makes it a resilient additional risk factor for coronary artery disease. In our study, there was no significant difference between groups for age $(p=0.66)$. In our current study, females (204) were more suffering from hyperuricemia in comparison to males (96) and the mean values of variables were somewhat similar to those of males. The risk of coronary artery disease is also attributable to the well known secondary association of hyperuricemia, essential hypertension, dyslipidemia, hyperinsulinemia, obesity and metabolic syndrome ${ }^{8 .}$ The current study revealed that there was marked increase in levels of uric acid in patients suffering from coronary artery disease with hyperuricemia $(8.22 \pm S D 0.39)(\mathrm{Cl} 8.17,8.26)$ when compared to controls (4.285 \pm SD 0.66) $(4.21,4.36)$. There was significant difference between groups of all the variables as revealed by our data $(p=0.001)$. Increased production of uric acid in cardiovascular disease can be due to the excess generation of adenosine by ischemia of cardiac and visceral tissue. Due to the low intracellular $\mathrm{pH}$ and negative membrane potential, whatsoever uric acid is formed by the degradation of adenosine accumulates in vascular lumen. Another possible reason of hyperuricemia in tissue ischaemia is the increase in xanthine oxidase activity $^{9}$. The present study revealed that there was marked increase in levels of LDL in patients of coronary artery disease with hyperuricemia (186.67 \pm SD24.019) (Cl 183.94, 189.40) when compared to coronary artery disease patients (160.16 \pm SD23.942) (Cl 157.44, 162.88). Hyperuricemia in turn promotes the oxidation of LDL which is key factor for the progression of artherosclerotic lesions, the hallmark of the coronary artery disease $\mathrm{e}^{15}$. The accumulated uric acid crystals activate the immune response in the patient and this plays a vital role in mediating inflammatory process via the inflammasome. Urate also impairs endothelial function via hyperlipidemias (LDL oxidation, cholesterol accumulation) and thereby gives rise to atherosclerotic risk $^{6}$. The present study also signifies that there was relevant increase in mean values of serum total cholesterol in patients of coronary artery disease with hyperuricemia (257.56 \pm SD22.65) (Cl 254.98, 260.13) when compared with patients of coronary artery disease (227.78 \pm SD22.65) (254.98, 260.13) and controls (173.22 \pm SD32.63), (Cl169.51,176.92). Hyperlipidemia causes altered endothelial function (dysfunction); adhesion of monocytes, increased permeability of endothelium resulting in adhesion of platelets and/or monocytes and release of PDGF (and 
other growth factors), which leads to smooth muscle migration and proliferation ${ }^{16}$. Smooth muscle cells produce large amounts of collagen, elastin, and proteoglycans forming the part of atheromatous plaque. Foam cells of atheromatous; from macrophages via the beta-VLDL receptor and also possibly by oxidized LDL. Accumulation of cholesterol in plaque is due to the imbalance between the influx and efflux. Oxidized LDL damages the endothelium leading to atherosclerosis by platelet adherence and formation of clot. Accumulation of cholesterol in plaque is due to the imbalance between the influx and efflux. VLDL remnants, chylomicron remnants, small dense LDL (sdLDL), Lp(a), and oxidized LDL are pro-atherogenic and HDLs are anti-atherogenic lipoproteins ${ }^{17}$. Metabolic derangements in gout and its relationship to the hyperlipidemias, artherosclerosis and inflammation provides us a conclusive and clear picture that due to hyperuricemia, incidence of coronary artery disease is significantly increasing.

\section{Conclusion}

A pervasive epidemic of coronary artery disease in developing countries may be inevitable unless there is a better understanding of its origins, a prediction of its magnitude, and the organization of preventive and casemanagement strategies early enough to control it. The presence of hyperuricemia, conveys an additional independent coronary artery disease risk factor. Hypercholesterolemia due to hyperuricemia is most common modifiable factor for coronary artery disease. Allopurinol and newer urate-lowering agents restores endothelial function in coronary artery disease patients. The ability of physicians to pharmacologically manage serum urate levels, a better understanding of the interactionbetweenhyperuricemia, gout and vascular disease may be critical for the reduction of morbidity and mortality in high-risk coronary artery disease patients.

\section{Conflict of Interests}

The authors do not have any conflict of interest arising from the study.

\section{Acknowledgements}

Dr. B M Nagpal, CEO, Manipal Education and Medical group \& Dean, Manipal College of Medical Sciences, P O Box No 155, Deep Heights Pokhara (Nepal) for permitting the authors to use the hospital documents during the study.

\section{References}

1. Gaziano TA. Reducing the growing burden of cardiovascular disease in the developing world. HealthAff (Millwood) $2007 ; 26(1): 13-24$.

2. Levenson JW, Skerrett PJ, Gaziano JM. Reducing the global burden of cardiovascular disease: the role of risk factors.PrevCardiol2002;5(4):188-99.

3. Hof D, Von Eckardstein A. [Risk factors in atherosclerotic coronary heart disease].TherUmsch 2009;66(4):253-9.

4. Okrainec K, Banerjee DK, Eisenberg MJ. Coronary artery disease in the developing world. Am Heart J 2004 ;148(1):715.

5. Verdier F, Fourcade L. [Changes in cardiovascular risk factors in developing countries].Med Trop (Mars)2007 ;67(6):552-8.

6. Krishnan E. Inflammation, oxidative stress and lipids: the risk triad for atherosclerosis in gout. Rheumatology (Oxford) 2010;49(7):1229-38.

7..Chizyński K, Rózycka M. .[ls hyperuricemia a cardiovascular risk factor?]. WiadLek. 2006;59(5-6):364-7.

8. Lim HE, Kim SH, Kim EJ, Kim JW, Rha SW, Seo HS et al. Clinical value of serum uric Acid in patients with suspected coronary artery disease. Korean J Intern Med 2010;25(1): 21-6.

9. Chopra S, Naithani M, Mahajan M, Bhagat S, Singh S. Uric acid as an additional risk factor in coronary artery disease in north Indians. Biomedical Research 2010; 21 (4): 365-8.

10. Viazzi F, Leoncini G, Ratto E, Pontremoli R. Serum uric acid as a risk factor for cardiovascular and renal disease: an old controversy revived. J ClinHypertens (Greenwich). 2006;8(7):510-8.

11. Friedel W. [Enzymatic Uric Acid Determination].Z Med Labortech. 1964;15:301-5.

12. Trinder P. Determination of serum cholesterol by enzymatic colorimetric method. Ann ClinBiochem 1969;6: 24-7.

13. Moshides S. Kinetic Enzymatic Method for Automated Determination of HDL Cholesterol in Plasma J ClinChemClin Biochem1987; 25: 583-7.

14. Warnick GR, Knopp RH, Fitzpatrick V, Branson L. Estimating low-density lipoprotein cholesterol by the Friedewald equation is adequate for classifying patients on the basis of nationally recommended cutpoints. ClinChem 1990;36(1):15-9.

15. Bagnati M, Perugini C, Cau C, Bordone R, Albano E, Bellomo $G$ et al. When and why a water-soluble anti-oxidant becomes pro-oxidant during copper-induced low-density lipoprotein oxidation: a study using uric acid.Biochem J 1999; 340:143-52.

16. Munro JM, Cotran RS. The pathogenesis of atherosclerosis: atherogenesis and inflammation. Lab Invest 1988;58(3):249-61.

17. Koba S, Hirano T. [Dyslipidemia and atherosclerosis]. Nihon Rinsho2011;69(1):138-43. 